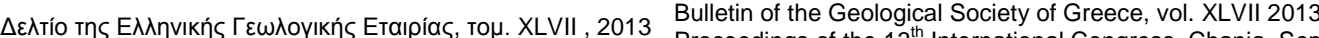
Proceedings of the $13^{\text {th }}$ International Congress, Chania, Sept.

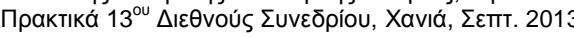
2013

\title{
MINERALOGICAL INVESTIGATION AND MINERAL PROCESSING OF IRON ORE FROM THE SKINES AREA (CHANIA - WEST CRETE)
}

\author{
Trichos D. ${ }^{1}$, Alevizos G. ${ }^{1}$, Stratakis A. ${ }^{1}$, Petrakis E. ${ }^{1}$ and Galetakis M. ${ }^{1}$ \\ ${ }^{I}$ Technical University of Crete, Department of Mineral Resources Engineering, Chania, Greece, \\ alevizos@mred.tuc.gr,astratak@mred.tuc.gr,vpetraki@mred.tuc.gr,galetaki@mred.tuc.gr
}

\begin{abstract}
Several iron ore occurrences are placed in the island of Crete and especially in the prefectures of Chania and Rethymno (Western Crete), some of which have been occasionally exploited. The aim of the present study is the mineralogical examination and the investigation of mineral processing potential of an iron ore occurrence located in the area of Skines village near to the city of Chania. The investigated iron ore occurrence form lenses which are placed within the contact of the phyllitequartzite of Phyllite-Quarzite-Series (PQS) of Crete and the overlaid limestones. The major minerals of the iron ore are goethite, hematite and quartz, while the less common are muscovite, lepidocrocite, gibbsite, talc and pyrite. The ore microscopy exanimation indicated that an extended epigenetic ferruginisation process has taken place. In general, mineral processing by using heavy liquid and magnetic separation did not give satisfactory results, except for the size fraction $-1+0,250 \mathrm{~mm}$ of the heavy liquid and the magnetic products of size ftactions $-8+4 \mathrm{~mm},-4+1 \mathrm{~mm}$ and $1+0,250 \mathrm{~mm}$. Ore microscopy examination of the different size fractions indicated that the difficulties in mineral processing are closely related to the ore liberation. Key words: Ore microscopy, epigenetic ferruginisation, Phyllite-Quartzite Series.
\end{abstract}

\section{Пєрí $\eta \psi \eta$}

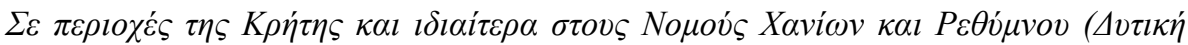

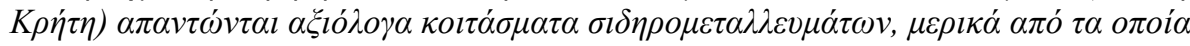

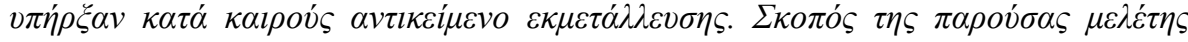

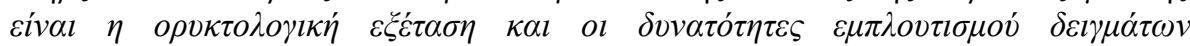

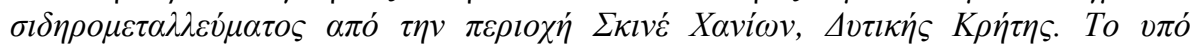

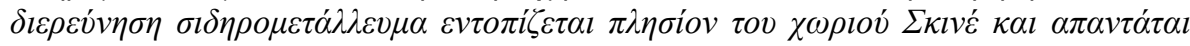

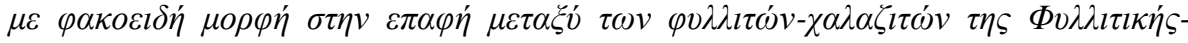

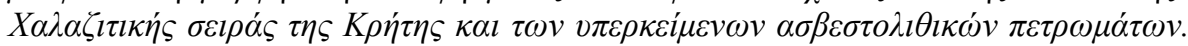

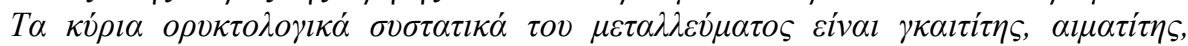

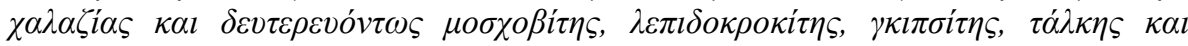

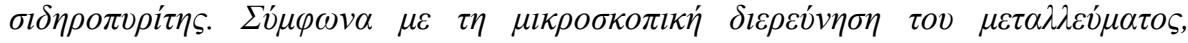

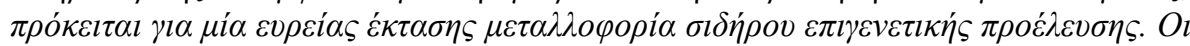

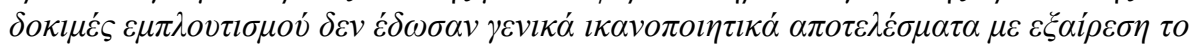

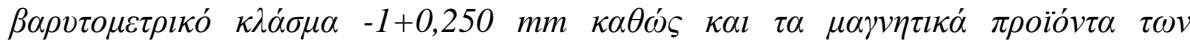

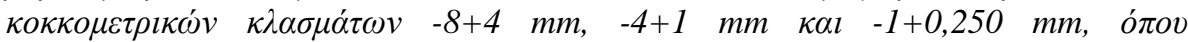

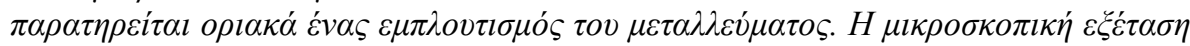

$\underline{\text { XLVII, No } 3-1652}$ 


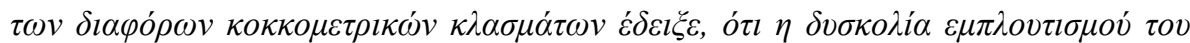

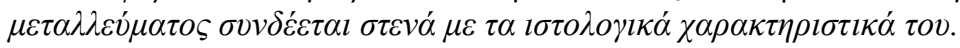

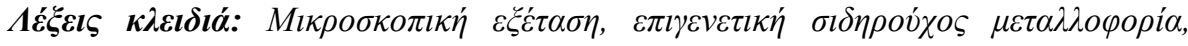

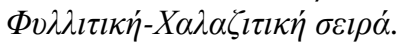

\section{Introduction}

Considerable iron ore deposits are placed in several regions of Greece, some of which were occasionally investigated for exploitation. Iron ore deposits which consist mainly of magnetite, hematite and limonite, have been mined up to 1964 (S.M.E., 1979). These iron ores are usually located into marbles or in contact with schists. The major deposits are those of Thassos, Kavala, Grammatico in Attica and Serifos. Occurrences of iron ore are located also in some islands of Cyclades and Eastern Aegean as well as in Peloponnese, Crete, Chalkidiki, Serres, etc. (Tsirampidis, 2005).

The quality of Greek iron ores is generally poor so they require mineral processing. The chemical composition of ores and particularly their content in iron, the character of the hosted minerals, as well as, the content of harmful elements are the main factors affecting their exploitability. Iron ores with content in iron above $52 \%$ are commercial as exploited, while poor ones with iron concentration between 20-52\%, must be enriched (Foufris, 1980). The content of harmful elements in iron ores should be under specific limits. According to Pohl (2005) the concentration of phosphorous in the ore should be under $0,045 \%$, the $\mathrm{Mn}$ under $2 \%$, the $\mathrm{Cr}$ under $1 \%$, the Ni under $0,5 \%$, the $\mathrm{S}$ under $0,2 \%$ and the $\mathrm{As}, \mathrm{Cu}, \mathrm{Zn}$ and $\mathrm{Pb}$ under $0,1 \%$.

Several iron ore occurrences are placed in Western Crete. The most important of these are found in the regions of Skines, Ravdoucha, Kakopetros, Drakona, Sklavopoula in the Prefecture of Chania, as well as, in the regions of Arolithi, Ano Valsamonero in the Prefecture of Rethymno. Iron ores of the regions Skines and Ravdoucha have been partially exploited. The aim of the present study is the mineralogical examination and the investigation of mineral processing of iron ore samples from the region of Skines. For the mineral processing tests of the iron ore samples, the heavy liquid and the magnetic separation methods were used.

\section{Geological and Deposit Setting}

The Phyllite-Quartzite Series (PQS) of Crete hosts several iron ore occurrences mainly in the western part of the island. The PQS contains mainly phyllites and quartzites as well as metaconglomerates, marbles, calcareous phyllites and metabasalts (Figure 1). The PQS and the Gypsum-Rauhwacke formation represent the lower unit of Phyllite Nappe of Crete. The Phyllite Nappe is a structural unit of external Hellenides, which is composed by the metamorphosed rocks lying between the Plattenkalk series underneath and Tripolitza series above (Dornsiepen and Manutsoglu, 1994).

According to Seidel et al. (2005), the iron ore deposits of Western Crete are hosted by an extensional detachment zone that is found in the upper parts of high pressure/low temperatures metamorphic Phyllite-Quartzite series. $\delta^{18} \mathrm{O}$ values of goethite from the iron deposits at Kakopetros and Ravdouxa in Western Crete indicate crystallization of iron ores at low temperatures between 310 and $40 \mathrm{oC}$ and at a depth of 1 to $1,5 \mathrm{~km}$, approximately.

Considerable iron ore occurrences are located near the Skines village about $17 \mathrm{~km}$ south-west of Chania. The investigated occurrence is placed around $1 \mathrm{~km}$ south of the village in the place named Chliaro. The largest part of the deposit lays in the slope of a hill in the form of lenses between phyllites underneath and limestones above. Except this deposit, there are other such occurrences in the region nearby but in a smaller extension (Papastamatiou, 1952). According to the researcher, the iron ore is composed of cellular limonite, which encloses grains of schists. In some places

$\underline{\text { XLVII, No } 3-1653}$ 
phyllite is impregnated by limonite. Limonite has penetrated into the brecciated phyllite and in a way it constitutes the matrix between grains of pre-existing minerals. The origin of iron ores can be associated to the presence of chalcopyrite, pyrite mineralization in the near village Fourne. The researcher considers that the appearances of iron ores in Western Crete come from the oxidation of Fe-sulfide deposits.

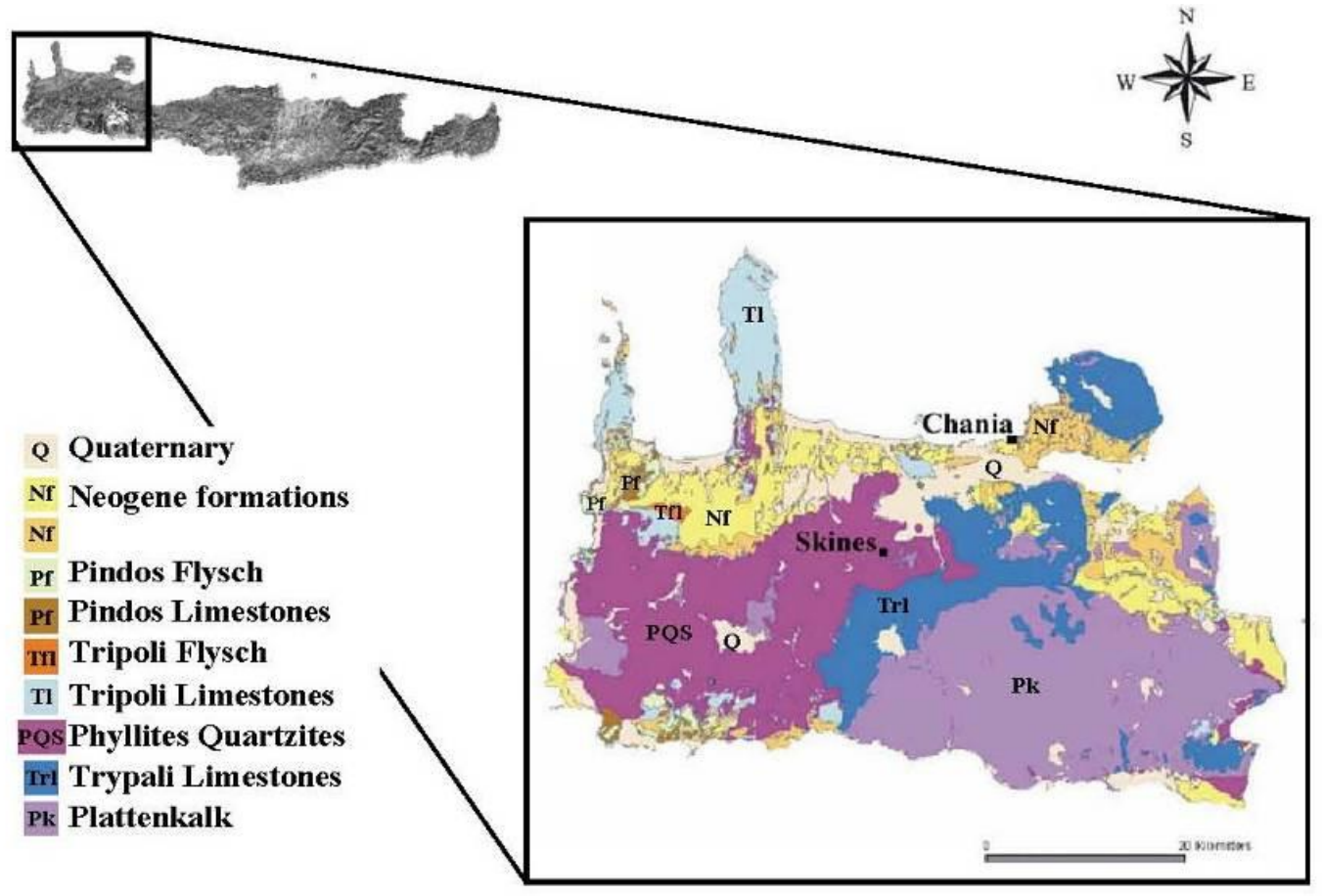

Figure 1 - Geological map of Skines area in western Crete (Electronic form of Geological Map of Greece, I.G.M.E. 1983, 2nd edition).

According to Mineral Resources Map (1965), six iron ore deposits occur in the south-east part of the Skines village. They consist mainly of limonite and hematite with low concentration in pyrolusite. They are placed in the contact of dolomites and phyllites and are considered of hydrothermal origin. The iron ore deposit has been partially mined in the past by the Mediterranean Group company (approximately 200 thousand tonnes have been extracted) while the remaining reserves of the deposit are estimated to 1 million tonnes.

\section{Experimental}

The mineralogical examination of the iron ore was carried out using the X-ray diffraction method. The automated X-ray diffractometer, D8 Advance of Bruker AXS company was used. The identification of the ore minerals and the description of the fabric, as well as, the examination of the intergrowth in the different products were performed via ore microscopy. A JENA ore microscope equipped with an OLYMPUS digital camera was used. The chemical analysis of iron ore was carried out using the automated X-ray fluorescence spectrometer, Bruker S2 Ranger. For the gravimetric separation of iron ore samples the heavy liquid Tetrabromoethane with density $\mathrm{d}=2,96 \mathrm{~g} / \mathrm{cm} 3$ was used. The magnetic separation was performed with the Perm Roll magnetic separator of IMPROSYS, as well as, with the high intensity Induced Roll Magnetic Separator MIH 111-5 of Carpco. 


\section{Mineralogy}

The iron ore deposit under investigation is located south of the village Skines and it forms lenses placed in the contact between the phyllite-quartzite and limestones. Several successive spot samples, from the top to the base of the exposed face, were taken. The collected samples were carefully selected to represent the alteration of the mineralization. The iron ore samples near the contact of phyllite-quartzites (base) are relatively rotten and are characterized by their reddishbrown colour. Samples collected from the middle and the upper part of the exposed iron ore face, are more compact and cohesive.

The microscopic examination and x-ray diffraction analysis of ore samples from the base of occurrence showed wide extent of ferruginisation mainly in the form of goethite, hematite and rarely lepidocrocite. The ferruginisation is developed between the grains of parent rocks of phyllite-quartzite replacing progressively the matrix (Figure 2). The major mineralogical component of these rocks is quartz and the minor ones are muscovite, talc and rarely gibbsite. The quartz is found in the form of allotriomorphic crystals that are fragmented to a large degree, as a result of tectonism of the parent rocks. A partial penetration of ferruginous solutions in capillary form was observed inside the quartzite grains. The iron ore is developed between the quartzite grains with the form of goethite and partially with the form of lepidocrocite. Goethite is formed in concentric shells along the gaps and fault zone, alternating gradually to hematite, because of dehydration. Crystals of pyrite in relatively small sizes were also observed occasionally scattered inside the iron ore. The presence of pyrite, as well as, lepidocrocite is also referred in iron rich breccien from Karanou area in Western Crete (Markopoulos et al., 2005).

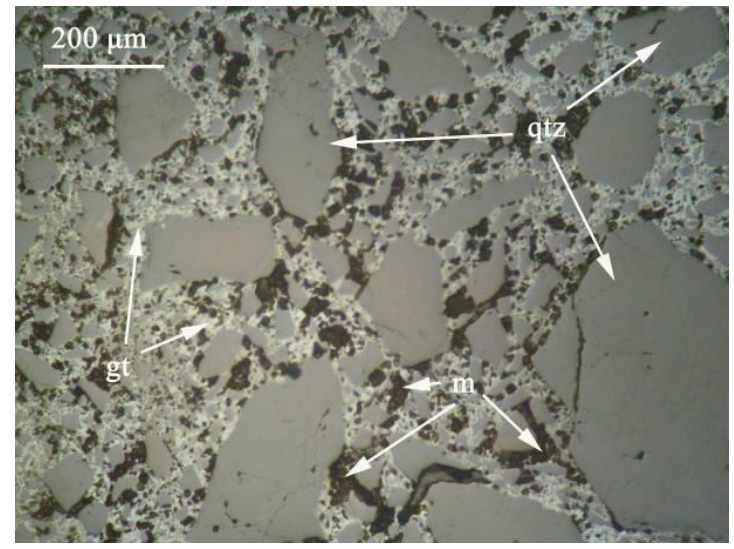

Figure 2 - Goethite replacing progressively the matrix between the grains of phyllitequartzite. (gt:goethite, qtz: quartz, m: matrix). Reflected light, // Nicols.

In the samples collected from the middle of the exposed face extensive ferruginisation was observed, which has been placed in the form of goethite replacing the binder between the grains. Goethite forms occasionally concentric shells along the cracks and gaps returning progressively into hematite (Figure 3). The quartz crystals are inequigranular, allotriomorphic and generally fragmented. The clay minerals, muscovite and talc, have a scale-like and an acicular form respectively, forming lenses that are developed between the quartzite grains. The x-ray diffraction analysis of a representative sample verified the presence of quartz $43 \%$, goethite $39 \%$, muscovite $11 \%$, gibbsite $3 \%$, hematite $2 \%$ and talc $2 \%$ wt equivalent.

In the upper parts of the exposed face of the iron ore occurrence, the microscopic examination showed an appreciable ferruginisation. The quartz is found mainly in the form of rough, inequigranular crystals. The ferruginisation developed in the form of goethite between the grains of parent rocks, as well as, along the cracks and gaps, providing cement shaped textures. Other mineralogical components are hematite, muscovite and gibbsite.

$\underline{\text { XLVII, No } 3-1655}$ 
According to the microscopic investigation of the samples collected from the ore face, an extended ferruginisation of epigenetic origin is evident. It is developed mainly in the form of goethite inside phyllite-quartzite, replacing gradually the binder between the grains. The fabric of the iron ore is generally characterized as cement shaped.

The chemical analyses of representative samples collected from the various parts of occurrence are presented in Table 1. The content of Fe2O3 in samples from the base of the face is $63.96 \%$, from the middle $63 \%$ and from the top $55.76 \%$ wt.

Concentrations of harmful elements in the initial sample show relatively small variations. The content of SO3 ranges between 0.12 and $0.18 \mathrm{wt} \%$, P2O5 between 0.19 and $0.48 \mathrm{wt} \%$, $\mathrm{ZnO}$ between 0.02 and $0.03 \mathrm{wt} \%$ and $\mathrm{MnO}$ between 0.34 and $0.41 \mathrm{wt} \%$ respectively. The $\mathrm{Cr} 2 \mathrm{O} 3$ content in the ore is up to $0.08 \mathrm{wt} \%$ (Table 1).

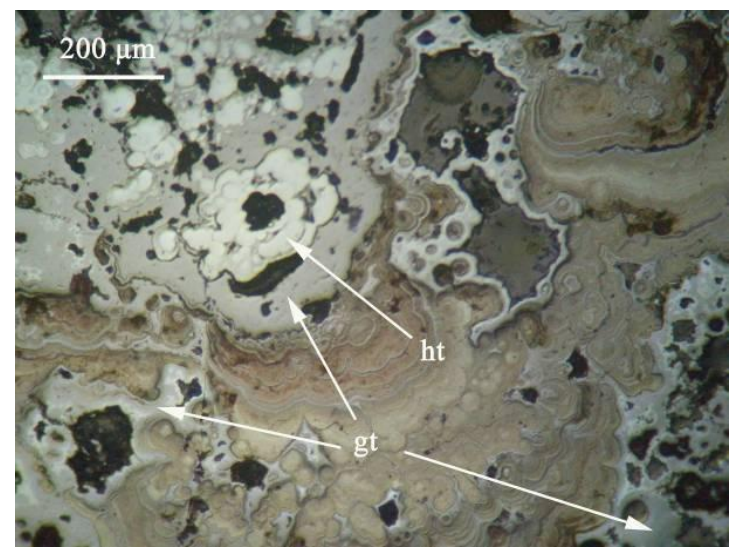

Figure 3 - Concentric shells of goethite alters progressively to hematite. (gt:goethite, ht:hematite) Reflecterd light, // Nicols.

Table 1 - Chemical composition (wt\%) of samples collected from different point of the exposed face of the iron ore occurrence.

\begin{tabular}{|c|c|c|c|c|c|c|c|c|c|c|c|c|c|c|}
\hline $\begin{array}{c}\text { Location } \\
\text { of sample }\end{array}$ & $\mathrm{SiO}_{2}$ & $\mathrm{Fe}_{2} \mathrm{O}_{3}$ & $\mathrm{Al}_{2} \mathrm{O}_{3}$ & $\mathbf{M g O}$ & $\mathrm{K}_{2} \mathbf{O}$ & $\mathbf{T i O}_{2}$ & $\mathbf{S O}_{3}$ & $\mathbf{C a O}$ & $\mathbf{M n O}$ & $\mathbf{P}_{2} \mathbf{O}_{5}$ & $\mathbf{Z n O}$ & $\mathbf{C r}_{2} \mathbf{O}_{3}$ & $\mathbf{L O I}$ & $\mathbf{S u m}$ \\
\hline $\begin{array}{c}\text { Base of } \\
\text { the face }\end{array}$ & 16.96 & 63.96 & 4.29 & - & 0.12 & 0.07 & 0.12 & 0.19 & 0.35 & 0.19 & 0.03 & - & 13.86 & 100.14 \\
\hline $\begin{array}{c}\text { Middle of } \\
\text { the face }\end{array}$ & 14.43 & 63.00 & 5.55 & 1.57 & 0.72 & 0.33 & 0.13 & 0.37 & 0.41 & 0.48 & 0.02 & 0.08 & 13.15 & 100.24 \\
\hline $\begin{array}{c}\text { Top of } \\
\text { the face }\end{array}$ & 24.69 & 55.76 & 5.69 & - & 0.18 & 0.12 & 0.18 & 0.22 & 0.34 & 0.21 & 0.02 & - & 12.67 & 100.08 \\
\hline
\end{tabular}

\section{Mineral Processing Tests}

\subsection{Experimental Procedure}

The collected bulk sample was crushed in size $-8 \mathrm{~mm}$ using a jaw crusher. The product of the jaw crusher was sieved into fractions of $-8+4 \mathrm{~mm},-4+1 \mathrm{~mm},-1+0,250 \mathrm{~mm}$ and $-0,250+0,063 \mathrm{~mm}$. These size fractions were divided into two equal parts for the magnetic and gravity separation tests. The fine fraction of $-0,063 \mathrm{~mm}$ is not suitable for these mineral processing tests and therefore it was not used. 
The gravimetric separation of the ore was carried out using the heavy liquid Tetrabromoethane with density $2.96 \mathrm{~g} / \mathrm{ml}$.

For the magnetic separation of fractions $-8+4 \mathrm{~mm}$ and $-4+1 \mathrm{~mm}$ the Perm Roll separator (equipped with permanent magnets) was used. Each fraction was separated with decreasing rotation speed starting with a rotation speed of $180 \mathrm{rpm}$, afterwards decreasing to $150 \mathrm{rpm}$ and finally to $100 \mathrm{rpm}$. With the above rotation speeds three successive passes of the material were carried out. In each pass the magnetic product is collected and weighed, while the non-magnetic is used to feed the next pass. In each pass the magnetic material is collected and at the final pass, at $100 \mathrm{rpm}$, the last magnetic and the final non-magnetic product were collected.

For the fractions $-1+0,250 \mathrm{~mm}$ and $-0,250+0,063 \mathrm{~mm}$ the Induced Roll magnetic separator was used. These fractions were separated initially with a rotation frequency $180 \mathrm{rpm}$ and electric current I = 1.6 A. From this process two products (a magnetic and a non-magnetic) were collected. The non-magnetic product was passed again from the separator at electric current $\mathrm{I}=3.2 \mathrm{~A}$ and the same frequency. At this pass the final magnetic and the final non-magnetic products were collected.

\subsection{Mineral Processing Results}

The chemical analyses of selected elements of the initial sample's size fractions are presented in Table 2. From the evaluation of chemical analyses in the different size fractions it is obvious that the content of the $\mathrm{Fe} 2 \mathrm{O} 3$ is reduced by reducing the size of the particles. The highest value is observed in fraction $-8+4 \mathrm{~mm}$, while there are small variations in the content of the intermediate size fractions. In contrast, the content of $\mathrm{SiO} 2$ increases gradually with the decrease of the grain size, indicating the smallest value in fraction $-8+4 \mathrm{~mm}$.

Table 2 - Chemical analysis of size fractions from initial sample.

\begin{tabular}{|c|c|c|c|c|c|c|}
\hline Size fractions & $\begin{array}{c}\text { Weight } \\
(\boldsymbol{\%})\end{array}$ & $\begin{array}{c}\mathbf{S i O}_{\mathbf{2}} \\
(\boldsymbol{\%})\end{array}$ & $\begin{array}{c}\mathbf{F e}_{\mathbf{2}} \mathbf{O}_{\mathbf{3}} \\
(\boldsymbol{\%})\end{array}$ & $\begin{array}{c}\mathbf{A l}_{\mathbf{2}} \mathbf{O}_{\mathbf{3}} \\
(\boldsymbol{\%})\end{array}$ & $\begin{array}{c}\mathbf{C a O} \\
(\boldsymbol{\%})\end{array}$ & $\begin{array}{c}\text { LOI } \\
(\boldsymbol{\%})\end{array}$ \\
\hline$-8+4 \mathrm{~mm}$ & 55.72 & 16.61 & 61.87 & 5.01 & 0.30 & 9.01 \\
\hline$-4+1 \mathrm{~mm}$ & 25.87 & 30.28 & 51.51 & 6.61 & 0.31 & 8.68 \\
\hline$-1+0.250 \mathrm{~mm}$ & 10.19 & 32.92 & 40.23 & 6.59 & 0.49 & 8.01 \\
\hline$-0.250+0.063 \mathrm{~mm}$ & 5.45 & 36.15 & 41.63 & 7.86 & 1.12 & 8.98 \\
\hline$-0.063 \mathrm{~mm}$ & 2.77 & 37.98 & 44.24 & 6.22 & 0.33 & 9.06 \\
\hline Total & 100.00 & 23.47 & 56.42 & 5.77 & 0.37 & 9.38 \\
\hline
\end{tabular}

\subsubsection{Gravimetric Separation}

The results of the gravimetric separation of the fractions $-8+4 \mathrm{~mm},-4+1 \mathrm{~mm},-1+0,250 \mathrm{~mm}$ and $0,250+0,063 \mathrm{~mm}$ are shown in Table 3 .

According to the results of Table 3, it is clear that the weight percentages of the sinks are generally higher compared to those of the floats for all size fractions. The content of Fe2O3 in the sinks is clearly higher (42-71 wt \%), while higher percentages are observed in coarser size fractions (Figure 4a). Similar conclusions emerge for the distribution of Fe2O3. In the sinks the distribution of this component ranges between 87-95 wt\%. The $\mathrm{SiO} 2$ shows, as expected, higher concentration compared to $\mathrm{Fe} 2 \mathrm{O} 3$ in the floats in all size fractions, except in the fraction $-4+1 \mathrm{~mm}$. The highest percentages of $\mathrm{SiO} 2$ are observed in the fractions $-1+0,250 \mathrm{~mm}$ and $-0,250+0,063 \mathrm{~mm}, 67 \%$ and $58 \mathrm{wt} \%$ respectively (Figure $4 \mathrm{~b}$ ). Of course, its distribution in the sinks is lower than that of $\mathrm{Fe} 2 \mathrm{O} 3$, while in the floats it has a higher value than that of Fe2O3. However, a significant percentage of $\mathrm{SiO} 2$ remains in the concentrate of several size fractions except the $-1+0,250 \mathrm{~mm}$, where the greater amount of $\mathrm{SiO} 2$ is moved to the floats (53\% versus $47 \mathrm{wt} \%$ in sinks).

XLVII, No $3-1657$ 
The above results are shown by the microscopic examination of size fractions. Figure 5a shows the sink product and Figure $5 \mathrm{~b}$ shows the float one of the fine size fraction $-0,250+0,063 \mathrm{~mm}$. It must be observed that even in the fine size fraction there are partially liberated ferrous mineral grains, matrix and quartz, which are driven in the sinks at the stage of mineral processing.

The chemical analyses of the size fractions showed that the $\mathrm{Fe} 2 \mathrm{O} 3$ has higher concentration in the sinks, while the $\mathrm{SiO} 2$ in the floats. Hence the corresponding mineralogical phases goethite, and hematite are mainly concentrated in the sinks while the quartz in the floats. The A12O3 presents the greatest concentrations mainly in the floats and therefore the minerals gibbsite, muscovite are concentrated in the tailing. The concentration of LOI that corresponds mainly to the presence of goethite is greater in the sink than the floats.

Table 3 - Results of gravimetric separation.

\begin{tabular}{|c|c|c|c|c|c|c|c|c|c|c|c|}
\hline \multirow[b]{2}{*}{$\begin{array}{c}\text { Size } \\
\text { fraction }\end{array}$} & \multirow[b]{2}{*}{ Products } & \multicolumn{2}{|c|}{ Weight (\%) } & \multicolumn{4}{|c|}{ Chemical analysis (\%) } & \multicolumn{4}{|c|}{$\begin{array}{l}\text { Distribution of the } \\
\text { fraction }(\%)\end{array}$} \\
\hline & & $\begin{array}{c}\text { of the } \\
\text { fraction }\end{array}$ & $\begin{array}{l}\text { of the } \\
\text { initial }\end{array}$ & $\mathrm{Fe}_{2} \mathrm{O}_{3}$ & $\mathrm{SiO}_{2}$ & $\mathrm{Al}_{2} \mathrm{O}_{3}$ & LOI & $\mathrm{Fe}_{2} \mathrm{O}_{3}$ & $\mathrm{SiO}_{2}$ & $\mathbf{A l}_{2} \mathbf{O}_{3}$ & LOI \\
\hline \multirow{3}{*}{$-8+4 \mathrm{~mm}$} & Float & 8.36 & 4.66 & 41.82 & 43.32 & 5.14 & 8.12 & 5.08 & 29.73 & 9.59 & 5.25 \\
\hline & Sink & 91.64 & 51.06 & 71.24 & 9.34 & 4.42 & 13.37 & 94.92 & 70.27 & 90.41 & 94.75 \\
\hline & Total & 100 & 55.72 & 68.78 & 12.18 & 4.48 & 12.93 & 100 & 100 & 100 & 100 \\
\hline \multirow{3}{*}{$-4+1 \mathrm{~mm}$} & Float & 16.69 & 4.32 & 43.93 & 39.46 & 5.62 & 9.06 & 12.90 & 26.80 & 15.63 & 13.64 \\
\hline & Sink & 83.31 & 21.55 & 59.43 & 21.60 & 6.08 & 11.50 & 87.10 & 73.20 & 84.37 & 86.36 \\
\hline & Total & 100 & 25.87 & 56.84 & 24.58 & 6.00 & 11.10 & 100 & 100 & 100 & 100 \\
\hline \multirow{3}{*}{$\begin{array}{c}-1+ \\
0.250 \mathrm{~mm}\end{array}$} & Float & 24.56 & 2.50 & 15.97 & 66.51 & 8.10 & 6.58 & 10.94 & 52.71 & 34.89 & 6.43 \\
\hline & Sink & 75.44 & 7.69 & 42.34 & 19.43 & 4.92 & 31.18 & 89.06 & 47.29 & 65.11 & 93.57 \\
\hline & Total & 100 & 10.19 & 35.86 & 30.99 & 5.70 & 25.14 & 100 & 100 & 100 & 100 \\
\hline \multirow{3}{*}{$\begin{array}{c}-0.250+ \\
0.063 \mathrm{~mm}\end{array}$} & Float & 12.21 & 0.67 & 22.41 & 57.66 & 13.64 & 3.75 & 6.25 & 20.97 & 22.57 & 3.93 \\
\hline & Sink & 87.79 & 4.78 & 46.77 & 30.23 & 6.51 & 12.76 & 93.75 & 79.03 & 77.43 & 96.07 \\
\hline & Total & 100 & 5.45 & 43.79 & 33.58 & 7.38 & 11.66 & 100 & 100 & 100 & 100 \\
\hline$-0.063 \mathrm{~mm}$ & Total & 100 & 2.77 & 44.24 & 37.98 & 6.22 & 9.06 & & & & \\
\hline \multicolumn{2}{|c|}{ Grand Total } & 100 & 100 & 60.30 & 19.19 & 5.20 & 4.10 & & & & \\
\hline
\end{tabular}
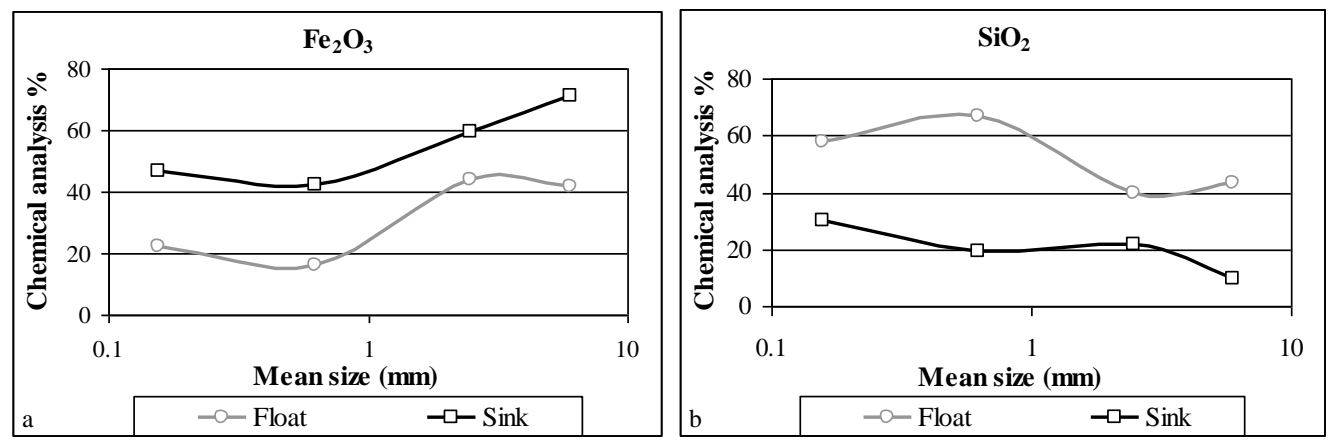

Figure 4 - Fe2O3 (\%wt) (a) and $\mathrm{SiO} 2(\% \mathrm{wt})(\mathrm{b})$ contents of the products obtained from the gravimetric separation.

$\underline{\text { XLVII, No } 3-1658}$ 

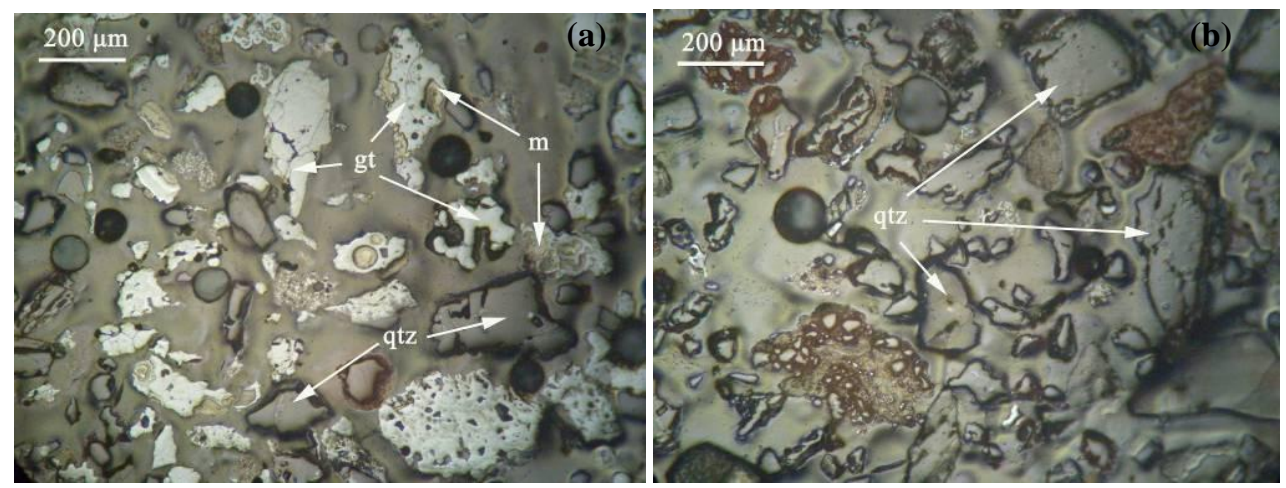

Figure 5 - Goethite grains and matrix partially liberated. Quartz is also present. (size

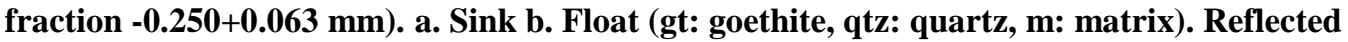
light, // Nicols.

\subsubsection{Magnetic Separation}

The results of magnetic separation in fractions $-8+4 \mathrm{~mm},-4+1 \mathrm{~mm},-1+0,250 \mathrm{~mm}$ and -0.250 $+0.063 \mathrm{~mm}$ are shown in table 4 . The main components in the various size fractions are $\mathrm{Fe} 2 \mathrm{O} 3$ and $\mathrm{SiO} 2$. The $\mathrm{Fe} 2 \mathrm{O} 3$ occurs in the ferrous minerals such as goethite and hematite, while the $\mathrm{SiO} 2$ is mainly found in quartz and in smaller quantities in the muscovite and talc. The $\mathrm{Al} 2 \mathrm{O} 3$ occurs in gibbsite and muscovite. The data of table 4 show that the percentages of magnetic products are higher than those of non-magnetic in both the coarser and fine size fractions. The content of $\mathrm{Fe} 2 \mathrm{O} 3$ is significantly greater in the magnetic products (44-63 wt \%) compared to those of nonmagnetic (8-34 wt \%). The $\mathrm{Fe} 2 \mathrm{O} 3$ content of all magnetic products decreases with the reduction of grain size (Figure 6a). On the contrary, the content of $\mathrm{SiO} 2$ is higher in non-magnetic products (50-71 wt\%) compared to magnetic ones (Figure 6b). Nevertheless, the content of $\mathrm{SiO} 2$ in the magnetic products is significant (16-35 wt\%) which indicates that the liberation of the minerals is not satisfactory. This was also confirmed by the microscopic examination of various size fractions (Figure $7 \mathrm{a}, \mathrm{b}$ ). Figure $7 \mathrm{a}$ shows a considerable amount of quartz, goes into the magnetic products due to the poor liberation of the specific size fraction.

The chemical analyses of size fractions shows that the $\mathrm{Fe} 2 \mathrm{O} 3$ is concentrated in the magnetic products and consequently the corresponding mineralogical phases goethite and hematite. Instead, the $\mathrm{SiO} 2$ is present in the non-magnetic products of all size fractions and therefore the mineral quartz. The concentration of $\mathrm{Al} 2 \mathrm{O} 3$ shows higher values in the non-magnetic products in all size fractions and consequently the minerals muscovite and gibbsite are mainly concentrated in the tailing. The LOI have greater values in the magnetic than in the non-magnetic products due to the concentration of goethite in these products.

\section{Discussion and Conclusions}

The ore deposit of Skines area Chania (West Crete) found in the form of lenses in the contact of phyllite-quartzite of Phyllite-Quartzite series of Crete and the overlaid limestones. The phyllitequartzite is strongly brecciated and is impregnated by limonite. Microscopic examination of the ore showed a widespread epigenetic ferruginisation.

The major minerals of the ore are goethite, hematite and quartz, while minor are muscovite, lepidocrocite, gibbsite, talc and pyrite. The ferruginisation is developed mainly in the form of goethite, hematite and rarely lepidocrocite within the brecciated phyllite-quartzite replacing gradually the matrix between the grains. The main mineralogical component of the parent rock is quartz with smaller percentage of muscovite, talc and the rarely gibbsite. 
Table 4 - Results of magnetic separation.

\begin{tabular}{|c|c|c|c|c|c|c|c|c|c|c|c|}
\hline \multirow[b]{2}{*}{ Size fraction } & \multirow[b]{2}{*}{ Products } & \multicolumn{2}{|c|}{ Weight (\%) } & \multicolumn{4}{|c|}{ Chemical analysis (\%) } & \multicolumn{4}{|c|}{$\begin{array}{l}\text { Distribution of the } \\
\text { fraction }(\%)\end{array}$} \\
\hline & & $\begin{array}{c}\text { of the } \\
\text { fraction }\end{array}$ & $\begin{array}{l}\text { of the } \\
\text { initial }\end{array}$ & $\mathrm{Fe}_{2} \mathrm{O}_{3}$ & $\mathrm{SiO}_{2}$ & $\mathrm{Al}_{2} \mathrm{O}_{3}$ & LOI & $\mathrm{Fe}_{2} \mathrm{O}_{3}$ & $\mathrm{SiO}_{2}$ & $\mathrm{Al}_{2} \mathrm{O}_{3}$ & LOI \\
\hline \multirow{6}{*}{$-8+4 \mathrm{~mm}$} & Magnetic 1 & 2.07 & 1.15 & 52.13 & 24.45 & 4.80 & 16.26 & 1.83 & 2.41 & 1.79 & 2.80 \\
\hline & Magnetic 2 & 64.24 & 35.79 & 63.79 & 15.44 & 5.62 & 12.79 & 69.49 & 47.15 & 65.17 & 68.32 \\
\hline & Magnetic 3 & 20.23 & 11.27 & 60.96 & 18.95 & 4.52 & 12.98 & 20.91 & 18.22 & 16.50 & 21.83 \\
\hline & Magnetic(Total) & 86.54 & 48.22 & 62.85 & 16.48 & 5.34 & 12.92 & 92.23 & 67.77 & 83.47 & 92.94 \\
\hline & Non magnetic & 13.46 & 7.50 & 34.04 & 50.35 & 6.80 & 6.30 & 7.77 & 32.23 & 16.53 & 7.06 \\
\hline & Total & 100 & 55.72 & 58.97 & 21.04 & 5.54 & 12.03 & 100 & 100 & 100 & 100 \\
\hline \multirow{6}{*}{$-4+1 \mathrm{~mm}$} & Magnetic 1 & 18.19 & 4.70 & 64.35 & 16.28 & 5.44 & 12.12 & 25.72 & 8.23 & 13.70 & 25.03 \\
\hline & Magnetic 2 & 42.36 & 10.96 & 54.76 & 25.35 & 6.36 & 10.80 & 50.98 & 29.84 & 37.30 & 51.93 \\
\hline & Magnetic 3 & 21.44 & 5.55 & 38.11 & 44.71 & 8.06 & 7.10 & 17.96 & 26.64 & 23.92 & 17.30 \\
\hline & Magnetic(Total) & 81.99 & 21.21 & 52.53 & 28.40 & 6.60 & 10.12 & 94.66 & 64.70 & 74.92 & 94.25 \\
\hline & Non magnetic & 18.01 & 4.66 & 13.50 & $|70.52|$ & 10.06 & 2.81 & 5.34 & $35.30 \mid$ & 25.08 & 5.75 \\
\hline & Total & 100 & 25.87 & 45.50 & 35.99 & 7.22 & 8.81 & 100 & 100 & 100 & 100 \\
\hline \multirow{5}{*}{$\begin{array}{c}-1+ \\
0.250 \mathrm{~mm}\end{array}$} & Magnetic 1 & 24.21 & 2.47 & 57.48 & 19.56 & 6.34 & 14.20 & 31.19 & 13.59 & 20.52 & 33.79 \\
\hline & Magnetic 2 & 42.92 & 4.37 & 54.76 & 23.98 & 6.79 & 11.22 & 52.69 & 29.53 & 38.96 & 47.35 \\
\hline & Magnetic(Total) & 67.13 & 6.84 & 55.74 & 22.39 & 6.63 & 12.30 & 83.88 & 43.12 & 59.48 & 81.14 \\
\hline & Non magnetic & 32.87 & 3.35 & 21.87 & 60.30 & 9.22 & 5.84 & 16.12 & 56.88 & 40.52 & 18.86 \\
\hline & Total & 100 & 10.19 & 44.61 & 34.85 & 7.48 & 10.17 & 100 & 100 & 100 & 100 \\
\hline \multirow{5}{*}{$\begin{array}{c}-0.250+ \\
0.063 \mathrm{~mm}\end{array}$} & Magnetic 1 & 69.48 & 3.79 & 46.83 & 31.57 & 7.40 & 9.69 & 82.57 & 56.64 & 61.67 & 78.25 \\
\hline & Magnetic 2 & 19.06 & 1.04 & 31.43 & 46.53 & 10.36 & 7.51 & 15.20 & 22.89 & 23.68 & 16.64 \\
\hline & Magnetic(Total) & 88.54 & 4.83 & 43.51 & 34.79 & 8.04 & 9.22 & 97.77 & 79.53 & 85.35 & 94.89 \\
\hline & Non magnetic & 11.46 & 0.62 & 7.68 & 69.15 & 10.65 & 3.83 & 2.23 & 20.47 & 14.65 & 5.11 \\
\hline & Total & 100 & 5.45 & 39.41 & 38.73 & 8.34 & 8.60 & 100 & 100 & 100 & 100 \\
\hline \multirow[t]{2}{*}{$-0.063 \mathrm{~mm}$} & Total & 100 & 2.77 & 44.24 & 37.98 & 6.22 & 9.06 & & & & \\
\hline & Grand Total & 100 & 100 & 52.55 & 27.75 & 6.34 & 10.74 & & & & \\
\hline
\end{tabular}
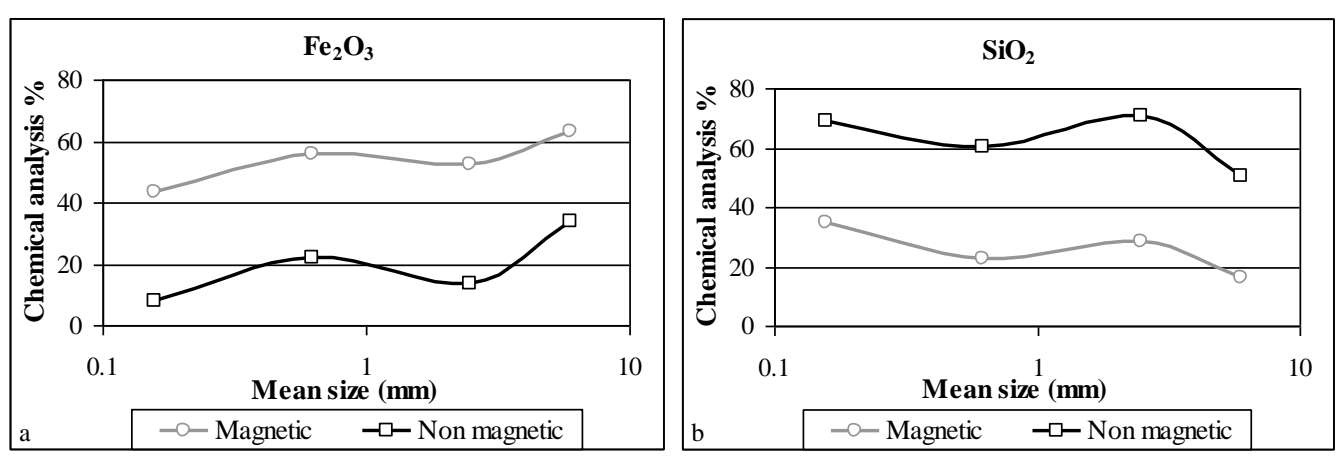

Figure 6 - Fe2O3 (\%wt) (a) and $\mathrm{SiO} 2(\% \mathrm{wt})$ (b) content of magnetic separation products. 

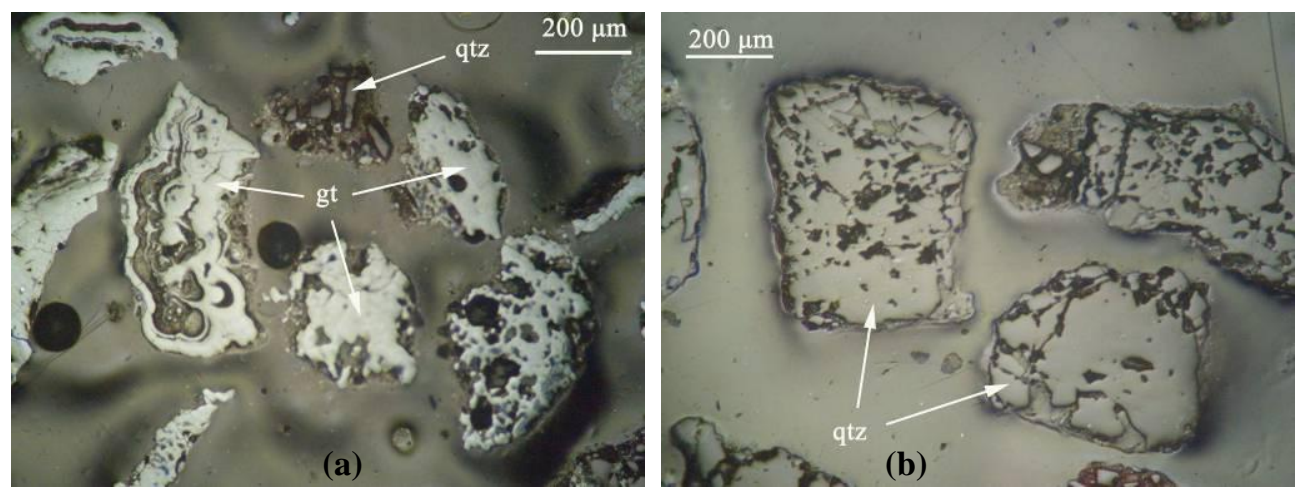

Figure 7 - Goethite grains with traces of quartz of size fraction $\mathbf{- 1 + 0 . 2 5 0} \mathbf{~ m m}$. a. Magnetic product 1 b. Non magnetic product. (gt: goethite, qtz: quartz). Reflected light, //Nicols.

Goethite often forms concentric shells along fault zone and gaps that gradually alters to hematite due to dehydration. Scattered pyrite crystals are occasionally observed in the ore. The fabric of the ore is generally characterized as cement shaped textures. The presence of pyrite in the ore residues reinforces the view that the formation of ore in Skines area can be related genetically to the existing Fe-sulfide mineralization near to Fournes village.

The gravimetric separation of the ore was moderately satisfactory. The weight percentages of the sinks is increased compared to those of the floats for all size fractions (75-92 wt \%). The content of $\mathrm{Fe} 2 \mathrm{O} 3$ is clearly greater in the sinks $(42-71 \mathrm{wt} \%)$. The $\mathrm{SiO} 2$ shows, as expected, slightly higher content related to $\mathrm{Fe} 2 \mathrm{O} 3$ in the floats in all size fractions except size fraction $-4+1 \mathrm{~mm}$, due to the poor liberation of the material in this fraction. The highest concentration $(67 \mathrm{wt} \%)$ is observed in the fraction of $-1+0,250 \mathrm{~mm}$. However a significant percentage of $\mathrm{SiO} 2$ remains in the concentrate of most size fractions except the size fraction $-1+0,250 \mathrm{~mm}$, where the greater part of $\mathrm{SiO} 2$ is driven to the floats (53\% versus $47 \mathrm{wt} \%$ in heavy).

The magnetic separation of the ore, generally, showed better results than those of the gravimetric separation. The weight percentages of magnetic products are much higher than those of nonmagnetic in both the coarser and fine size fractions. The concentration of $\mathrm{Fe} 2 \mathrm{O} 3$ is higher in the magnetic products (44-63 wt\%) compared to the non-magnetic (8-34 wt\%), while the recovery varies between 84 and $98 \mathrm{wt} \%$ in all size fractions. On the other hand, the $\mathrm{SiO} 2$ shows a higher concentration in the non-magnetic products (50-71 wt \%) compared to the magnetic ones. However a significant percentage, between 16 and $35 \mathrm{wt} \%$, remains in the magnetic products.

The mineral processing tests were moderately satisfactory, except for the fraction $-1+0,250 \mathrm{~mm}$ of the gravimetric separation and the magnetic products 2 of size fractions $-8+4 \mathrm{~mm},-4+1 \mathrm{~mm},-1$ $+0,250 \mathrm{~mm}$ of the magnetic separation, as shown by the distribution of these fractions. According to the $\mathrm{Fe} 2 \mathrm{O} 3$ content in all size fractions of mineral processing tests, it is obvious that the ore cannot be considered to be commercially exploitable $\left(74.3 \% \mathrm{Fe}_{2} \mathrm{O}_{3}\right.$ or $\left.52 \% \mathrm{Fe}\right)$, except for the size fraction $-8+4 \mathrm{~mm}$ of the gravimetric separation $(71 \%)$.

Microscopic examination of the different size fractions showed that the liberation of ferrous minerals from waste rock was not satisfactory. This is due to the fact that the goethite replacing the matrix between the granules of the parent rock and often penetrates by capillary-needle form in the quartz grains thus makes difficult their separation. The tests of the ore processing confirmed the results of microscopic investigation of the different size fractions which had shown that the mineral processing of the examined ore could be difficult due to its formation and its fabric characteristics. 


\section{References}

Dornsiepen U. F. und Manutsoglu E. 1994. Zur Gliederung der Phyllit-Decke Kretas und des Peloponnes, Z. dt. geol. Ges., 145, 286-304.

Greek Mining Enterprises association (S.M.E) 1979. The Greek Mineral Wealth, Athens 696 pp. (in Greek)

Markopoulos Th., Alevizos G., Manutsoglu E. and Repouskou E. 2005. Mineralogische und erzmikroskopische Untersuchung eisenvererzter Breccien aus der Karanouregion, WestKreta, Griechenland., Ber. Deutsch. Mineral. Ges., Beih. z. Eur. J. Mineral., v.17, 86.

Mineral Resources Map 1965. Explanatory issue of Metallogenetic Map of Greece, 1:1.000.000, P ublished by Institute for Geology and Subsurface Research, 1973, Athens, 254 p. (in Greek)

Papastamatiou J. 1952. The mineral wealth of Crete, Institute of Geological and Mining Research, Report No 256, Athens, 38 pp. (in Greek).

Pohl W. L. 2005. Mineralische und Energie-Rohstoffe. 5 Auflage, E. Schweizerbart'sche Verlagsbuchhandlung (Naegele u. Obermiller), S.527.

Seidel M., Pack A., Sharp Z. and Seidel E. 2005. The Kakopetros and Ravdoucha iron-oxide deposits, Western Crete, Greece: Fluid transport and mineralization within a detachment zone, Economic Geology, v.100, 165-174.

Tsirampidis A. 2005. The mineral wealth of Greece, Editors Jachoudi, Thessaloniki, 391 pp. (in Greek).

Fufris A. 1980. Study on possibility of enrichment poor iron ores of Serifos Island, Report, No 23, I.G.M.R., Athens, 40 pp. (in Greek). 